\title{
A comparison of some laboratory techniques for the estimation of the digestibility of the organic matter in forage samples
}

\author{
C. J. van der Koelen and A. J. H. van Es \\ Institute for Animal Feeding and Nutrition Research 'Hoorn', Hoorn, the Netherlands
}

Accepted: 26 February 1973

\section{Summary}

An interlaboratory comparison of some chemical techniques for predicting digestibility of organic matter of roughage was made. To this purpose 194 samples of roughage of known digestibility in vivo were analysed. These were classified into six groups according to the nature of the material: grass hay, other dried roughages, fresh grass, other fresh roughages, grass silage and other silages. For all roughages together and for each separate group in vivo digestibility values were regressed on the results obtained with each of ten different chemical techniques, and correlation coefficients ( $r$ ) and residual standard deviations (rsd) were computed.

For all roughages split up in groups better results for $\mathbf{r}$ and rsd were obtained than for all roughages together.

All techniques gave better results than the crude fibre content, which in our country is used on a large scale. The best predictor of digestibility of the organic matter of roughage was in each of the six groups the slightly modified in vitro technique of Tilley and Terry. The technique of cell-wall constituents of Gaillard and Nijkamp exceeded this method, however, in a collection of 54 samples from all groups, but in this case the rsd was higher than those found within the groups. The in vitro technique of Tilley and Terry required least time; it, however, requires rumen fluid, to be provided, for example, by donor-sheep.

\section{Introduction}

The energetic feeding value of roughages is closely related to the digestibility of their organic matter. Since the determination of digestibility with animals (in vivo) takes much time and requires large quantities of material, several chemical methods have been developed to estimate the energetic feeding value from the figures obtained with the chemical analysis. In the Netherlands we use the crude fibre content for this purpose (Brouwer \& Dijkstra, 1938).

The prediction of the digestibility in this way is very simple, but it has some disadvantages. The crude fibre fraction has no steady composition and varies with plant species, stage of growth and method of conservation.

Especially for ensiled products the crude fibre content is not a reliable criterion to predict the energetic feeding value (van der Koelen \& Dijkstra, 1971).

In the last decade throughout the world numerous studies have been made in which digestibility in vivo has been correlated with the results of various other determinations. 
For this reason some years ago in our country several such techniques were investigated at several institutes. Each institute worked on one or two different techniques. The necessity was felt to coordinate the work in such a way that the results could be compared, also between institutes. For this purpose a working group was established comprising workers from the Institute for Biological and Chemical Research on Field Crops and Herbage, the Institute for Research on Storage and Processing of Agricultural Produce, the Institute for Animal Feeding and Nutrition Research 'Hoorn' and the Departments of Animal Physiology and of Field Crops and Grassland Husbandry of the Agricultural University. The task of this group was to find out which of the various techniques used for predicting the digestibility of the organic matter would fit in best with the digestibility in vivo and which was most suited for routine application. It appeared impossible to select the best method only on the basis of theoretical views. So it was decided to analyse a large collection of samples with known digestibility in vivo, according to the methods which were being studied at some of these institutes.

\section{Material of the comparison}

The material used to compare the different techniques was delivered by the Institute for Animal Feeding and Nutrition Research 'Hoorn'. It consisted of 194 forages whose digestibility was determined with wethers fed slightly above the maintenance level. For several reasons most workers analysed only part of the sample collection. The results therefore could not always be compared as a whole.

\section{Description of the various techniques}

a. The two-stage technique for digestion in vitro (van der Koelen \& Dijkstra, 1971') The technique (Tilley \& Terry, 1963) in which the dried and ground material is incubated for 48 hours with rumen fluid, and another 48 hours with acid-pepsin, was simplified and made more suitable for routine analysis (van der Koelen, et al., 1969²). The results obtained were corrected with the help of two standard samples, which were analysed in triplicate during each run because of possible differences between runs. This technique was used at the Institute for Animal Feeding and Nutrition Research 'Hoorn'.

\section{b. The determination of cell-wall constituents (Gaillard \& Nijkamp, 1968)}

In this technique three contents are determined (in $\%$ of dry matter of the sample):

1. Neutral-detergent residue (NDR);

2. Anhydro-uronic acid in NDR (U);

3. Lignin in NDR $\left(\mathrm{L}_{n}\right)$.

For a description of the technique we refer to the publication of Gaillard \& Nijkamp (1968). Statistical analysis of the results obtained showed that the digestibility in vivo of the organic matter (IVpr) could be predicted with the following regression equation:

$$
\mathrm{IVpr}=-4.64\left(\mathrm{~L}_{\mathrm{n}}-5.19\right)-0.14(\mathrm{NDR}-48.05)+2.95(\mathrm{U}-3.47)+66.7
$$

\footnotetext{
1 In this paper, published in 1971, i.e. after the activities of the working group, 262 samples were used including the 194 samples studied in this article.

: A translation of this article in English can be obtained on request from the Institute for Animal Feeding and Nutrition research 'Hoorn', Keern 33, Hoorn, the Netherlands.
} 
This technique was developed and used at the Department of Animal Physiology of the Agricultural University.

c. The determination of cell-wall constituents (Bosman, 1970)

In this technique also three contents are determined:

1. Neutral-detergent residue (NDR) (Van Soest \& Wine, 1967);

2. Acid-detergent residue (ADR) (Van Soest, 1963);

3. Lignin in ADR ( $\left.\mathrm{L}_{\mathrm{a}}\right)$ (Van Soest, 1963; slightly modified).

To predict the digestibility in vivo of the organic matter (IVpr) several simple and multiple regression equations were derived from the results with the percentages of NDR, ADR and $L_{a}$ as independent variables.

To compare the results of this technique with the other techniques two regression equations which gave the best fit to the in vivo data were selected:

$$
\begin{aligned}
& \mathrm{IVpr}=0.98(100-\mathrm{NDR})+\mathrm{NDR}\left(1.57-0.926 \log \mathrm{L}_{\mathrm{a}}\right)-5.81 \\
& \mathrm{IVpr}=-0.453 \mathrm{NDR}+0.901 \mathrm{ADR}-6.342 \mathrm{~L}_{\mathrm{ad}}+90.42
\end{aligned}
$$

in which:

$\mathrm{L}_{\mathrm{a}}=$ percentage of lignin in ADR

$\mathrm{L}_{\mathrm{ad}}=\mathrm{L}_{\mathrm{a}}$ as a percentage of the organic matter of the sample.

NDR and ADR are expressed as a percentage of the organic matter of the sample. Eq. 2 was derived from 50 samples at random chosen from the total set of 194 forages; the other equation from 22 grass samples. This technique was used at the Institute for Biological and Chemical Research on Field Crops and Herbage.

d. The determination of cell-wall constituents (Deinum \& Van Soest, 1969)

In this technique too three contents are determined (in $\%$ of organic matter of the sample):

1. Acid-detergent residue (ADR);

2. Neutral-detergent residue (NDR);

3. Lignin in ADR $\left(\mathbf{L}_{\mathbf{a}}\right)$.

For a description of the procedure we refer to publications of Van Soest (1963) and Van Soest \& Wine $(1967,1968)$.

Three regression equations were derived from the material used in this paper:

$$
\begin{aligned}
& \mathrm{IVpr}=0.98(100-\mathrm{NDR})+\mathrm{NDR}\left(0.88-0.39 \log \mathrm{L}_{\mathrm{a}} / \mathrm{ADR}\right)+4.5 \\
& \mathrm{IVpr}=0.98(100-\mathrm{NDR})+\mathrm{NDR}\left(1.27-0.67 \log \mathrm{L}_{\mathrm{a}} / \mathrm{ADR}\right)+0.5 \\
& \mathrm{IVpr}=0.98(100-\mathrm{NDR})+\mathrm{NDR}\left(1.40-0.78 \log \mathrm{L}_{\mathrm{a}} / \mathrm{ADR}\right)-0.7
\end{aligned}
$$

The equations differ slightly from those mentioned in the paper of Deinum \& Van Soest (1969).

Eq. 4 was calculated for grasses, Eq. 5 for grasses and legumes and Eq. 6 for all samples.

In their paper Deinum \& Van Soest use the terms 'acid-detergent fiber' and 'cell-wall constituents', which are the same as our 'acid-detergent residue' and 'neutral-detergent residue', respectively.

The technique was used by a worker at the Department of Field Crops and Grassland Husbandry during his stay at the Laboratory of the Animal Husbandry Research Division in Beltsville (USA). 
e. The determination of lignin (Muller et al., 1970)

After extraction with ether and with water in a boiling water-bath the lignin content (e $e_{1}$ was determined by a treatment with $72 \%$ sulphuric acid, followed by refluxing with $3 \%$ sulphuric acid. The lignin fraction was analysed for nitrogen and the proteinfree lignin content $\left(e_{2}\right)$ calculated. The contents are expressed as a percentage of the organic matter. By Muller no formulae were given to predict the digestibility in vivo of the organic matter. This technique was developed and used at the Institute for Research on Storage and Processing of Agricultural Produce.

\section{The model}

The general model used by the members of the working group for predicting the digestibility in vivo of the organic matter (IVpr) was:

$$
\mathrm{IVpr}=\mathrm{a}_{1} \mathrm{C}_{1}+\mathrm{a}_{2} \mathrm{C}_{2}+\ldots+\mathrm{a}_{\mathrm{n}} \mathrm{C}_{\mathrm{n}}+\mathrm{k},
$$

in which: $a_{1}, a_{2}$ etc and $k$ are constants

$\mathrm{C}_{1}, \mathrm{C}_{2}$ etc are contents in dry matter or organic matter.

To obtain the values of the various constants, they calculated regressions of the known digestibilities in vivo of their samples against contents. A few workers not only derived regression equations according to this model for all the samples analysed, but also for parts of the whole set.

\section{Results and discussion}

The digestibility figures of the organic matter are given in Table 1 . Within each technique the in vivo results were regressed against the results obtained with Technique a and on the results obtained for the separate samples with the regression equations of

Table 1. Correlation between the digestibility in vivo of the organic matter and the data obtained with the different techniques for all samples as one group.

\begin{tabular}{|c|c|c|c|c|c|c|c|c|}
\hline $\begin{array}{l}\text { Tech- } \\
\text { nique }\end{array}$ & $\begin{array}{l}\text { Number } \\
\text { of } \\
\text { samples }\end{array}$ & $\begin{array}{l}\text { Average } \\
\text { digestibility } \\
\text { in vivo of } \\
\text { organic } \\
\text { matter }\end{array}$ & $\begin{array}{l}\text { Average } \\
\text { relevant } \\
\text { data }\end{array}$ & $\begin{array}{l}\text { Average } \\
\text { relevant } \\
\text { data* }\end{array}$ & $r$ & $\mathbf{r}^{*}$ & rsd & rsd* \\
\hline a & 194 & 67.8 & 67.7 & - & 0.91 & - & 3.20 & - \\
\hline b & 54 & 65.2 & 64.8 & 66.0 & 0.96 & 0.94 & 2.86 & 3.33 \\
\hline$c_{1}$ & 83 & 67.0 & 66.4 & 67.1 & 0.92 & 0.92 & 3.28 & 3.29 \\
\hline$c_{2}$ & 34 & 69.8 & 69.4 & 70.0 & 0.92 & 0.95 & 2.99 & 2.23 \\
\hline$d_{1}$ & 120 & 67.0 & 71.6 & 68.0 & 0.83 & 0.92 & 3.88 & 2.83 \\
\hline $\mathrm{d}_{2}$ & 120 & 67.0 & 64.8 & 68.0 & 0.76 & 0.92 & 4.58 & 2.83 \\
\hline$d_{3}$ & 120 & 67.0 & 61.6 & 68.0 & 0.75 & 0.92 & 4.65 & 2.83 \\
\hline $\mathbf{e}_{\mathbf{1}}$ & 77 & 68.7 & 11.0 & 68.1 & -0.89 & 0.94 & 3.43 & 2.55 \\
\hline$e_{2}$ & 77 & 68.7 & 8.9 & 68.1 & -0.93 & 0.94 & 2.72 & 2.55 \\
\hline f & 194 & 67.8 & 28.8 & 67.7 & -0.71 & 0.91 & 5.32 & 3.20 \\
\hline
\end{tabular}

* Relevant data according to Technique a for the same group of samples as mentioned in the second column. 
Techniques $b, c$ and $d$. The figures to which the in vivo results were compared were called 'relevant data'. The calculation procedure used for Techniques $b, c$ and $d$ had the advantage that multiple regression calculations were not necessary.

For our purpose this gives the same information regarding coefficients of correlation and residual standard deviations as when the in vivo values once more had been directly regressed on the appropriate contents. The columns $r$ and rsd show the correlation coefficients and the residual standard deviations, respectively, of the regression computations. For Technique $e_{1}$ only lignin ( $\%$ of organic matter) and for Technique $\mathrm{e}_{2}$ only protein-free lignin (\% of organic matter) were used as independent variables ('relevant data') because no regression equation had been given. In Table 1 we also find the crude-fibre content of the dry matter (f) determined at the Institute for Animal Feeding and Nutrition Research 'Hoorn', according to the Weende analysis. The in vivo results were also directly regressed on these values $f$.

Assuming that all sets of samples smaller than 194 at random chosen from the total set, have the same distribution as the total set we may conclude that Techniques $a, b$, $c_{1}, c_{2}, e_{1}$ and $e_{2}$ give better results than Techniques $d_{1}, d_{2}, d_{3}$ and $f$. The correlation coefficients of those techniques are high and the residual standard deviations relatively moderate (6th and 8th column, respectively). Table 1 clearly shows that all techniques described in this paper give better results than the crude-fibre content (f) as a predictor of digestibility.

Supposing that the assumption made might be incorrect the calculations were repeated for Technique a with the sets of samples used for Techniques b, c, d, e and $f$. Now we can compare the figures predicted with Technique a with the figures predicted by the other techniques applied on the same sets of samples. In Table 1 the figures with ruference to the calculations can be found in the columns marked with an asterisk $\left({ }^{*}\right)$. From these figures we see that Technique $a$ is in most cases superior to the other techniques. Only Technique $b$ gives a better prediction. This technique was devised to predict the digestibilities of a wide variety of roughages with the same equation. The 54 samples selected did indeed vary considerably in nature.

As the roughages used for the comparison were very different it was decided to classify them into six groups: grass hay, other dried roughages, fresh grass, other fresh roughages, grass silage and other silages. For each group of roughages the figures mentioned in Table 1 were calculated. The results for the groups grass hay, fresh grass and grass silage are given in Table 2 . The results of the groups other dried roughages, other fresh roughages and other silages are not given for the following reasons:

1. The number of samples used for the calculations was in most cases too small to obtain reliable results.

2. Within each group each investigator analysed a number of roughages at his own choice. These numbers comprising only incidentally the same samples, could therefore hardly be used for an appropriate comparison.

3. The figures obtained with these three groups are in good agreement with those from the grass products.

Table 2 shows that division into groups reduces the residual standard deviation in almost all cases. Only in the group fresh grass analysed with Techniques $e_{1}$ and $e_{2}$ the residual standard deviations are somewhat higher. Comparing the results of the same groups of samples analysed by Technique a with those analysed by the other techniques we must conclude again that Technique a gives in almost all cases higher correlation coefficients and lower residual standard deviations. An exception is the group grass silage analysed according to Technique $c_{1}$. 
Table 2. Correlation between the digestibility in vivo of the organic matter and the data obtained with the different techniques for the three main groups.

\begin{tabular}{llllllll}
\hline $\begin{array}{l}\text { Tech- } \\
\text { nique } \\
\text { of } \\
\text { samples }\end{array}$ & $\begin{array}{l}\text { Average } \\
\text { digestibility } \\
\text { in vivo of } \\
\text { organic } \\
\text { matter }\end{array}$ & $\begin{array}{l}\text { Average } \\
\text { data }\end{array}$ & $\begin{array}{l}\text { Average } \\
\text { relevant } \\
\text { data* }\end{array}$ & $\mathbf{r}$ & $\mathbf{r}^{*}$ & rsd & \\
& & & & & & \\
rsd $^{*}$
\end{tabular}

\begin{tabular}{lr}
\multicolumn{2}{c}{ Grass } \\
$\mathrm{a}$ & 75 \\
$\mathrm{~b}$ & 6 \\
$\mathrm{c}_{1}$ & 8 \\
$\mathrm{c}_{2}$ & 8 \\
$\mathrm{~d}_{1}$ & 56 \\
$\mathrm{~d}_{2}$ & 56 \\
$\mathrm{~d}_{3}$ & 56 \\
$\mathrm{e}_{1}$ & 16 \\
$\mathrm{e}_{2}$ & 16 \\
$\mathrm{f}$ & 75
\end{tabular}

$\begin{array}{rr}66.6 & 66.3 \\ 65.7 & 66.0 \\ 67.0 & 66.2 \\ 67.0 & 66.0 \\ 66.4 & 7.02 \\ 66.4 & 59.3 \\ 66.4 & 54.6 \\ 65.2 & 12.1 \\ 65.2 & 9.6 \\ 66.6 & 30.3\end{array}$

-
66.0
67.8
67.8
67.0
67.0
67.0
65.9
65.9
66.3

0.88
0.94
0.87
0.90
0.83
0.84
0.84
-0.90
-0.93
-0.78

-
0.99
0.99
0.99
0.92
0.92
0.92
0.98
0.98
0.88

$\begin{array}{ll}2.13 & - \\ 2.27 & 0.88 \\ 3.22 & 0.94 \\ 2.93 & 0.94 \\ 2.57 & 1.77 \\ 2.51 & 1.77 \\ 2.52 & 1.77 \\ 3.14 & 1.54 \\ 2.65 & 1.54 \\ 2.76 & 2.13\end{array}$

Fresh grass

$\begin{array}{lr}\text { Fresh } & \text { grass } \\ \mathbf{a} & 41 \\ \mathrm{~b} & \\ \mathrm{c}_{1} & 22 \\ \mathrm{c}_{2} & 22 \\ \mathrm{~d}_{1} & 12 \\ \mathrm{~d}_{2} & 12 \\ \mathrm{~d}_{3} & 12 \\ \mathbf{e}_{1} & 22 \\ \mathrm{e}_{2} & 22 \\ \mathrm{f} & 41\end{array}$

$\begin{array}{rr}72.2 & 71.1 \\ 74.3 & 72.2 \\ 72.3 & 71.4 \\ 72.3 & 71.4 \\ 72.3 & 73.9 \\ 72.3 & 71.2 \\ 72.3 & 69.6 \\ 71.3 & 10.3 \\ 71.3 & 8.2 \\ 72.2 & 26.8\end{array}$

-
74.9
72.0
72.0
73.4
73.4
73.4
70.7
70.7
71.1

0.93
0.91
0.92
0.92
0.64
0.81
0.82
-0.85
-0.92
-0.81

-
0.91
0.93
0.93
0.80
0.80
0.80
0.94
0.94
0.93

$$
2.57
$$

Grass silage

\begin{tabular}{|c|c|c|c|c|c|c|c|c|}
\hline \multicolumn{9}{|c|}{ Whass stekge } \\
\hline $\mathrm{a}$ & 30 & 72.1 & 70.8 & - & 0.85 & - & 2.46 & - \\
\hline b & 6 & 73.7 & 71.2 & 73.3 & 0.97 & 0.98 & 0.98 & 0.88 \\
\hline$c_{1}$ & 19 & 72.7 & 69.7 & 71.2 & 0.88 & 0.84 & 2.40 & 2.72 \\
\hline $\mathrm{d}_{1}$ & 18 & 72.4 & 74.3 & 71.9 & 0.65 & 0.88 & 2.97 & 1.86 \\
\hline $\mathrm{d}_{\mathbf{2}}$ & 18 & 72.4 & 72.3 & 71.9 & 0.66 & 0.88 & 2.93 & 1.86 \\
\hline $\mathrm{d}_{3}$ & 18 & 72.4 & 71.0 & 71.9 & 0.66 & 0.88 & 2.93 & 1.86 \\
\hline$e_{1}$ & 26 & 72.4 & 9.9 & 71.1 & -0.70 & 0.84 & 3.34 & 2.56 \\
\hline $\mathrm{e}_{2}$ & 26 & 72.4 & 7.9 & 71.1 & -0.82 & 0.84 & 2.71 & 2.56 \\
\hline $\mathrm{f}$ & 30 & 72.1 & 28.5 & 70.8 & -0.36 & 0.85 & 4.37 & 2.46 \\
\hline
\end{tabular}

* Relevant data according to Technique a for the same group of samples as mentioned in the second column.

For routine applications of a technique it is desirable that a large number of samples can be determined in a relatively short time. The number of simplo determinations which were analysed by one person in one week with Techniques $a, b, c, d$, e and $f$ was about $60,30,25,50,20$ and 40 , respectively. However it should be remarked that since the activities of the working group the efficiency of some of the techniques has been considerably improved. As to method a the demand for donor-animals providing rumen fluid is an additional disadvantage. 


\section{Conclusions}

All techniques described in this paper predict the digestibility of the organic matter of roughages better than the crude fibre content. Comparing the results, obtained with the different techniques mentioned in this paper, we can conclude that the slightly modified in vitro technique of Tilley \& Terry (a) gave the best fit with digestibility in vivo of the organic matter within the main groups of roughages grass hay, other dried roughages, fresh grass, other fresh roughages, grass silage and other silages. It also required the least laboror per sample; it, however, needed donor-animals for rumen fluid. To predict digestibility for all roughages put together in one group, the technique of cellwall constituents by Gaillard \& Nijkamp (b) exceeded the modified Tilley \& Terry technique (a) slightly, but the residual standard deviation in this case was higher than the deviations within the groups. The labour required by Technique $b$ is rather high, but it does not require donor-animals for rumen fluid as with Technique a.

\section{References}

Bosman, M. S. M., 1970. Methods of predicting herbage digestibility II. Commun. Note Inst. biol. chem. Res. Field Crops Herbage 413.

Brouwer, E. \& N. D. Dijkstra, 1938. Onderzoek naar de voederwaarde van Nederlandse hooisoorten en naar hun invloed op de eiwit-, kalk- en phosphorstofwisseling bij jonge runderen. Versl. Landbouwk. Onderz. 44 (12) C: 529-612.

Deinum, B. \& P. J. van Soest, 1969. Prediction of forage digestibility from some laboratory procedures. Neth. J. agric. Sci 17: 119-127.

Gaillard, B. D. E. \& H. J. Nijkamp, 1968. Calculation of the digestibility for ruminants of roughages from their contents of cell-wall constituents. II Time-saving method of analysis. Neth. J. agric. Sci. 16: $21-24$.

Koelen, C. J. van der, A. Kemmink \& N. D. Dijkstra, 1969. De bepaling van de voederwaarde van ruwvoeders met behulp van de in vitro-verteerbaarheid. Internal Rep. Inst. Anim. Feeding Nutr. Res. 'Hoorn' 27.

Koelen, C. J. van der \& N. D. Dijkstra, 1971. Bepaling van de verteerbaarheid in vitro als hulpmiddel bij de schatting van de voederwaarde van ruwvoeders. Landbouwk. Tijdschr. 83: 494 499.

Muller, F. J., J. G. Dijkhuis \& S. Heida, 1970. On the relationship between chemical composition and digestibility in vivo of roughage. Agric. Res. Rep. 736.

Tilley, J. M. A. \& R. A. Terry, 1963. A two-stage technique for the in vitro digestion of forage crops. J. Br. Grassld. Soc. 18: $104-111$.

Van Soest, P. J., 1963. Use of detergents in the analysis of fibrous feeds. I. Preparation of fibre residues of low nitrogen content.J. Am. Org. agric. Chem. 46: 825-829.

Van Soest, P. J., 1963. Use of detergents in the analysis of fibrous feeds. II. A rapid method for the determination of fibre and lignin. J. Am. Org. agric. Chem. 46:829-835.

Van Soest, P. J. \& R. H. Wine, 1967. Use of detergents in the analysis of fibrous ffeeds. IV. Determination of plant cell-wall constituents. J. Am. Org. agric. Chem. 50: 50-55.

Van Soest, P. J. \& R. H. Wine, 1968. The determination of lignin and cellulose in acid-detergent fibre with permanganate. J. Am. Org. agric. Chem. 51: 780-785. 